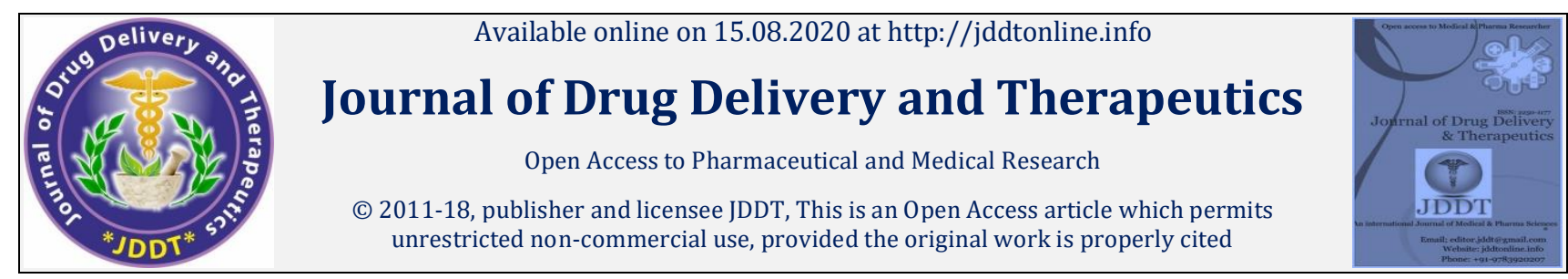

Open@Access

Research Article

\title{
Conceptual Study on Effect of Edagajadi Yoga and Gandhapashanadi Lepa in the Management of Sidhma Kushtha W.S.R. to Pityriasis Versicolor
}

\author{
Dr. Radhika S Pukale1*, Dr. Harish Bhakuni², Dr. Abhishek Upadhyay ${ }^{3}$ \\ 1P.G. Scholar, Final Year, P. G. Dept. of Kayachikitsa, National Institute of Ayurveda, Jaipur, India \\ ${ }^{2}$ Assistant Professor, P. G. Dept. of Kayachikitsa, National Institute of Ayurveda, Jaipur, India \\ ${ }^{3}$ Lecturer, P. G. Dept. of Kayachikitsa, National Institute of Ayurveda, Jaipur, India
}

\begin{abstract}
Tinea versicolor is a common superficial fungal infection of the skin, prevalent in the hot and humid environment of India. It is caused by the Malassezia species which is a dimorphic, lipophilic fungus most frequently affecting the seborrheic areas of the body like face, neck, upper back and chest. Normally 10-15\% of the general practitioner's encounter skin disorders in their day to day practice with overall prevalence rate of $30 \%$ or more probably occurring in tropical zones. Kustha a type of skin disorder mentioned in Ayurveda is a Tridoshaja Vyadhi, where Twaka, Rakta, Mamsa and Ambu are the main Dushyas. According to Charaka, Sidhma is a Kapha Vata Pradhan Vyadhi and According to Sushruta, Sidhma is Kapha Pradhan vyadhi. Management of sidhma includes Shodhana, Shamana and Bahirparimarjana Chikitsa among them Shamana in the form of kwatha \& Bahirparimarjana Chikitsa as Lepa has shown appreciable result in many previous researches. So, need of time is to go for cost effective, safe and efficient treatment of Sidhma. Although, there are many drugs available in modern medical science for the treatment of Pityriasis versicolor which is found to be effective but is unsatisfactory for long term prophylaxis, so there is need of the hour to look into the safe, efficient \& satisfactory remedy which not only treat the above ailments, but also ensure reduction in the episodes of relapse of the disease. Keeping all the above points in mind Edagajadi yoga \& Gandhapashanadi lepa has been selected to know its efficacy in treating Sidhma kushtha (Pityriasis versicolor). Edagajadi yoga \& Gandhapashanadi lepa consists of 10 drugs with different properties which includes Edagaja, Vidanga, Haridra, Daruharidra, Amlatasa, Kushta, Pippali, Gandhak, yavkshar, sarshapa taila.
\end{abstract}

Keywords: Sidhma, Pityriasis versicolor, Edagajadi yoga, Gandhapashanadi lepa

Article Info: Received 11 June 2020; Review Completed 08 July 2020; Accepted 17 July 2020; Available online 15 August 2020 Cite this article as:

Pukale RS, Bhakuni H, Upadhyay A, Conceptual Study on Effect of Edagajadi Yoga and Gandhapashanadi Lepa in the Management of Sidhma Kushtha W.S.R. to Pityriasis Versicolor, Journal of Drug Delivery and Therapeutics. 2020; 10 (4s):25-30 http://dx.doi.org/10.22270/jddt.v10i4-s.4198

*Address for Correspondence:

Dr. Radhika S Pukale, P.G. Scholar, Final Year, P. G. Dept. of Kayachikitsa, National Institute of Ayurveda, Jaipur, India

\section{INTRODUCTION}

Pityriasis versicolor is also known as tinea versicolor, dermatomycosis perforatia, tinea flava, liverspots or achromia parasitica is a chronic recurring non-contagious superficial mycotic infection characterized by scaly, dyspigmented irregular macules most often occurring on the trunk and extremities. Skin pigmentary changes occurring on the lesions are due to colonization of the stratum corneum by a dimorphic lipophilic fungus known as Malassezia furfur yeast ${ }^{1}$. Increase in humidity, temperature and carbon dioxide tension are important predisposing factors ${ }^{2,3}$. An overall prevalence rate of $30 \%$ or more probably occurs in tropical zones, the actual frequency of the disease in temperate climates is not known 4 .

Tinea versicolor is generally a disease of mature adults when the sebaceous glands are most active, with 2:1 prevalence

ISSN: 2250-1177 ratio in female \& male patients; however, studies performed in the tropics indicate that tinea versicolor in childhood is common $^{5}$. According to Acharya Charaka ${ }^{6}$, Sidhma is characterized by fine branny desquamation, appearing similar to the color of Alabupushpa (Lagenaria siceraria (Mol.) Standl). The lesions of Sidhma are white or coppery in color resembling to P. versicolor in terms of scaling, site and color of the lesion. Sidhma is categorized under Mahakushtha by Acharya Charaka \& in Kshudra kushtha by Acharya Sushrutha means the type of Kushtha which neither progresses nor decreases but remains static for a longer time. Acharya Dalhana clarifies there are two types of Sidhma Kushtha as Sidhma \& Pushpikasidhma. The Doshadushya sammurchhana in Pushpikasidhma is weak, local immunity is strong \& hence the samprapti does not invade the consecutive dhatus at all \& gets cured earlier. Haranachandra, the commentator of Sushruta Samhita has 
given the meaning of 'Apayi' as the disappearing in the winter season and 'Akastakari' i.e. not troublesome to the patient.

Pityriasis versicolor is caused by Malassezia yeast, a dimorphic fungus ${ }^{7}$. and a member of normal skin flora of human beings which under certain conditions, transforms into filamentous pathogenic forms ${ }^{8}$. Malassezia, the causal agent of Pityriasis versicolor is preferred to be same polymorphic organism as $P$. orbiculare and $P$. ovale by its historic value. The change in budding blastospore form to the hyphal form is under the influence of endogenous and exogenous predisposing factors. In patients affected with $P$. ovale, the lesions of tinea versicolor were found mainly on the trunk i.e below the waistline, buttocks, and thighs, whereas those with $P$. orbiculare had a predilection for the chest, neck, face, and upper limbs. Overgrowth of microorganism is caused by triggering factors like increased temperature, humidity, immunosuppression, hormonal imbalance, excessive oily skin, increased TEWL mainly on seborrheic areas or in population with hyperhidrosis ${ }^{9}$.

\section{Rationale}

Dravya is an organized thing. Property of a substance can be changed but not the substance. Ayurveda uses drug as a whole for therapeutic activity therefore it remains organized. According to Ayurveda, Dravya (Aushadha) is considered as one of the four-fold constituents of "chikitsa chatushpada", which works on seven parameters like rasa, guna. veerya, vipaka \& prabhava. Ayurveda gives importance to immunity instead of microbes; thus, drugs have pharmaco-therapeutic effect instead of having pharmaco-dynamic effect. The right choice of dravya helps in reversing or breaking the samprapti without producing any side effects.

A number of formulations have been mentioned in Ayurvedic classics for the treatment of Sidhma Kushtha. Vata and kapha are the predominant dosha involved in the pathogenesis of
Sidhma kushtha. Therefore, the treatment should be focused on vata-kapha hara line along with swedakelda upashoshana, krimi nashaka \& srotoshodhana of rasadi srotas.

Keeping aforesaid points in mind \& considering previous evident researches Edagajadi Yoga(kwatha) as well as Gandhapashanadi lepa has been selected for internal shodhana and bahirparimarjan chikitsa respectively to know their effectiveness \& reliability in treating Sidhma kushtha

\section{Aims and Objectives}

To evaluate the role of Edagajadi yoga and Gandhapashanadi lepa in the management of Sidhma kushtha with special reference to Pityriasis versicolor.

\section{MATERIAL AND METHODS}

Ayurvedic textbooks were referred to collect the relevant materials.

The index, non-index medical journals were referred to collect relevant information.

Drug Review: Even the ancient sages were well aware of skin conditions like Sidhma kushtha and various descriptions regarding the disease have been mentioned in different classical textbooks by different Acharyas. Moreover, the Acharyas have mentioned several herbs and formulation in the management of Sidhma kushtha. They all are potent in its own way in the management of Sidhma kushtha. Out of many such formulations, the aforesaid combinations were selected for the study.

\section{Edagajadi yoga (Kwatha)}

एडगजः सविडड़ोो द्वे च निशे राजवृक्षमूलं च| कुष्ठोद्दालनमग्रं सपिप्पलीपाकलं योज्यम्||२६?।|

-Ref Cha.chi (Kushtha chikitsa 07/161)

Table 1: Quantity of Ingredients taken for preparation of Edagajadi yoga (kwatha).

\begin{tabular}{|l|l|l|l|l|}
\hline S.No & Drug (Sanskrit) & Botanical name & Part used & Quantity \\
\hline $\mathbf{1}$ & Edagaja & Cassia tora & Seeds & 1 part \\
\hline 2 & Vidanga & Embelia ribes & fruit & 1 part \\
\hline 3 & Haridra & Curcuma longa & Rhizome & 1 part \\
\hline 4 & Daruharidra & Berberis aristata & Root & 1 part \\
\hline 5 & Amlatasa & Cassia fistula & Root & 1 part \\
\hline 6 & Kushta & Saussurea lappa & Root & 1 part \\
\hline 7 & Pippali & Piper longum & Fruit & 1 part \\
\hline
\end{tabular}

\section{Preparation of Edagajadi yoga (kwatha).}

All the seven dry herbs 1-7 were collected in required amount and grinded into coarse powder. The raw drugs were grinded into pulverizer and filtered in sieve with mesh number 22.

\section{Gandhapashanadi lepa}

\section{गन्धपाशाणचूर्णेन यवक्षारेण लेपितम। सिध्म नाशं व्रजन्त्याशु कटु तैलयुतेन च ॥}

Ref: Bhaishajya. Ratnavali, Kushtha Roga adhikar 54/25)
Table 2: Quantity of Ingredients taken for preparation of Gandhapashanadi lepa

\begin{tabular}{|l|l|l|}
\hline S.no. & Sanskrit Name & Quantity \\
\hline 1. & Shuddh Gandhak & 1 part \\
\hline 2. & Yavakshar & 1part \\
\hline 3 & Sarshapataila & As per needed \\
\hline
\end{tabular}




\section{Preparation of Gandhapashanadi lepa}

The two dry ingredients 1-2 were collected in required amount and grinded into fine powder. This mixture was then filtered out in sieve and mixed in the form of homogenous consistency.

\section{Results:}

On thorough analysis of the ingredients in Ayurveda classics and recent pharmaco-analytical researches reported, a sufficient \& effective data was obtained. The drugs selected exhibits the following properties and pharmacological activity, specific against the causative factors of sidhma kushtha as well as against the pathogenicity of Malassezia spp. in pityriasis versicolor.

Table 3: Showing properties and pharmacological action of ingredients

\begin{tabular}{|c|c|c|c|c|c|c|}
\hline Drug & Rasa & Guna & Veerya & Vipaka & Dosaghnata & Karma \\
\hline Chakramarda & Kațu & Laghu, Rukșa & Ușna & Kațu & Kaphavatahara & $\begin{array}{l}\text { MedaDadrukandu } \\
\text { hara } \\
\text { Kanti saukumar } \uparrow \\
\text { (D.N) }\end{array}$ \\
\hline Vidanga & $\begin{array}{c}\text { Katu, } \\
\text { Kashaya }\end{array}$ & Laghu, Rukșa, Tiksna & Ușna & Kațu & Kaphavatahara & $\begin{array}{c}\text { Krimighna,kusthag } \\
n a\end{array}$ \\
\hline Haridra & Kațu ,Tikta & Laghu, Rukșa & Ușna & Kațu & KaphaPitta Shamak & $\begin{array}{c}\text { Kandughna } \\
\text {,krimighna } \\
\text { Deha- } \\
\text { varnvidhayini }\end{array}$ \\
\hline Daruharidra & Kațu ,Tikta & Rukșa & Ușna & Kațu & Kapha-Pitta Shamak & $\begin{array}{l}\text { Kandughna } \\
\text { Tiktarasayana } \\
\text { (D.N) }\end{array}$ \\
\hline Aragwadha & $\begin{array}{l}\text { Madhura, } \\
\text { Tikta }\end{array}$ & Guru. snigdha .mridu & Sheeta & Madhura & Vata-Pitta Shamak & $\begin{array}{l}\text { Kusthaghna, } \\
\text { kandughna, } \\
\text { raktashodhak }\end{array}$ \\
\hline Kushtha & $\begin{array}{l}\text { Tikta, Kațu } \\
\text { Madhura }\end{array}$ & Laghu, Rukșa, Tikșṇa & Ushna & Kațu & Kapha-vata śamaka & $\begin{array}{l}\text { Kushthamarut- } \\
\text { kaphan(B.P) }\end{array}$ \\
\hline Pippali & Kațu & $\begin{array}{l}\text { Laghu,,Snigdha, } \\
\text { Tikșna }\end{array}$ & $\begin{array}{l}\text { Anușna } \\
\text { Sita }\end{array}$ & Madhura & Vata-Kapha Śamaka & $\begin{array}{c}\text { Deepana pachana } \\
\text { Medanashini, } \\
\text { Kriminashini } \\
\text { (cha.Su) }\end{array}$ \\
\hline Sarshapa taila & Katu tikta & $\begin{array}{c}\text { Tikshna Snigdha, } \\
\text { laghu }\end{array}$ & Ushna & Katu & kaphaVatahara & $\begin{array}{c}\text { Krimighna, } \\
\text { kandughna, } \\
\text { ksuhthagna(su.su } \\
\text { 45) }\end{array}$ \\
\hline Gandhak & $\begin{array}{l}\text { Madhura, } \\
\text { Katu, Tikta, } \\
\text { Kashaya }\end{array}$ & Ushna, Sara, Snigdha & Ushna & Katu & $\begin{array}{l}\text { KaphaVatahara, } \\
\text { Pittavardhaka }\end{array}$ & $\begin{array}{c}\text { Dadru, Garavisha, } \\
\text { kushtha, Kandu }\end{array}$ \\
\hline Yavakshara & Katu & $\begin{array}{l}\text { Tikshna,Ushna, } \\
\text { Laghu,Ruksha }\end{array}$ & Ushna & - & Kaphavatahara & $\begin{array}{l}\text { Lekhana, } \\
\text { Varnavardhak, } \\
\text { krimighna }\end{array}$ \\
\hline
\end{tabular}

\section{Chakramarada}

Chakramarda seeds have phytochemical constituents like anthraquinone glycosides, naptho-pyrone glycosides, cassiaside etc. which showed significant hepatoprotective activity. Thrachrysone, isolated from seeds, showed stronger antioxidant activity than tocopherol and BHA. Chrysophanic acid-9-anthrone, extracted from the seed, was found to be active against ringworm fungi ${ }^{10} \&$ is been found to have Hypolipidemic action ${ }^{11}$ (showed marked reduction in serum concentration of total cholesterol and triglyceride level). It possesses strong antifungal action against Candida albicans,
Aspergillus niger, Sachharomyces cerevisiae and Trichophyton mentagrophyte ${ }^{12}$ along with Anti-inflammatory activity against histamine, serotonin and dextran induced oedema ${ }^{13}$.

\section{Vidanga}

A recent study with ethyl acetate (EA) and petroleum ether (PE) extracts of 16 Indian medicinal plants from 15 different families were subjected to screen growth inhibitory potential against M.furfur. Amongst all extracts, the maximum degree of activity was observed in Embelia ribes. The EA and PE extracts of E. ribes have shown considerable 
growth inhibition potential against M. furfur i.e of about 65 and $77 \%$, respectively. ${ }^{14}$ 'Embelin' a major phytochemical constituent of E. ribes against M. furfur, was isolated from herb as described by Madhavan et al. (2011) ${ }^{15}$. The higher activity of hydrophobic extract (PE) and non-responsiveness of hydrophilic counterpart (M) indicated the hydrophobic nature of the active principle responsible for antifungal activity in E. ribes against M. furfur. Since the hydrophobic compound 'embelin' has been reported as the major and signature phytochemical of E. ribes ${ }^{16}$, it is conjectured that embelin would be the molecule responsible for antifungal activity of E. ribes against M. furfur.

\section{Haridra}

As per the research, Haridra contains Curcumin which showed significant anti-inflammatory activity ${ }^{17}$.Water- and fat-soluble extracts of turmeric and its curcumin component exhibit strong antioxidant activity, comparable to vitamins $\mathrm{C}$ and $E^{18}$.Wuthiudomlert et al. (2000) who reported the antifungal activity of turmeric oil against 29 clinical strains of dermatophytes found that diameter of inhibition zone on screening of turmeric oil was found to vary from $26.1 \mathrm{~mm}$ to $46 \mathrm{~mm}$ against 29 clinical strains of dermatophytes ${ }^{19}$. The study conducted by Sharma et al displayed the strong antifungal activity against M. furfur. On screening, it was observed that the turmeric rhizome showed the diameter of inhibition zone by disc diffusion method ( $55 \mathrm{~mm}$ ) against $\mathrm{M}$. furfur at $100 \%$ concentration of pure oil 20 .

\section{Daruharidra}

The most active ingredient of the plant is berberine, a quaternary isoquinoline alkaloid and the content of berberine-typically found in the roots, rhizomes and stem bark. It has immune-stimulating, anti-inflammatory, antimicrobial, antifungal 21 , antiprotozoal activities. ${ }^{22}$ The MIC value of the B.aristata root extract against M. furfur was found to be $100 \mu \mathrm{g} / \mathrm{ml}^{23}$ which indicates that it could be a good source for the anti-fungal medicine. ${ }^{24}$ The efficacy of such herbal agents in acne treatment is not only based on anti-microbial activity but also on their antioxidant and anti-inflammatory properties as well by which they inhibit neutrophil migration and generation of reactive oxygen species ${ }^{25}$. B. aristata is used in skin diseases due to its skin detoxification property ${ }^{26}$.

\section{Aragwadha}

C. fistula was found beneficial in treatment of Sidhma Kushta (pityriasis versicolor) ${ }^{27}$. The hydroalcoholic extracts of Cassia fistula leaves contained tannins, flavonoids, saponins, triterpenoids, steroids, glycosides, anthraquinones, reducing sugars, carbohydrates, proteins, and amino acids ${ }^{28}$. Results show that plant rich in tannin and phenolic compounds have been shown to possess antimicrobial activities against a number of microorganisms ${ }^{29}$ C. fistula showed strong antimicrobial effect against superficial dermatophytes predominantly towards $M$. furfur with Inhibition zones $>10$ $\mathrm{mm}$ indicating strong antimicrobial activity 30 \& antifungal activity 31 . The hydroalcoholic extracts of Cassia fistula were found to be active on most of the clinically isolated microorganism and fungi, as compared with standard drugs. 32

\section{Kushtha}

This plant contains active principles like saussurine, costunolide, lactones and the pharmacological activity of this plant reported for its hepatoprotective, hypoglycemic, antidiabetic, anti-inflammatory, antiviral, and antifungal effects ${ }^{33}$. In a study by Abdullah et al $S$. costus has showed high significant level of antifungal activity ${ }^{34}$. In the scientific literature, the biological activities of the roots of S. costus (synonymous with S.lappa) are widely investigated. Scientific investigations revealed that it has antitrypanosomal activity (Julianti et al, 2011) \& has "complement-inhibitor" substances helpful in the treatment of some diseases related to excessive activation of the complement system, like rheumatoid arthritis, respiratory distress and systemic lupus erythematosus (Fan et al., 2014). It was published that S.costus has a good anticancer activity tested on cell lines (Robinson et al., 2008). The ethanol extract of S.lappa (synonymous S.costus) recorded a wide spectrum antimicrobial activity against some human pathogens (Hasson et al., 2013). In addition, many investigations reported other bioactive properties of $S$. costus roots such as anti-ulcer, anti-inflammatory, hepatoprotective, immunomodulator, hypoglycaemic, spasmolytic, anticonvulsant, antidiarrheal and antiviral activity (Zahra et al., 2014 Ghansham et al., 2017).

\section{Pippali}

Malassezia fungus is an exception because it occurs as opportunistic yeast in humans as well as in other animals. M. furfur is of significant importance for its action on human skin \& scalp causing pityriasis versicolor, dandruff and responsible for skin \& hair disorders. The percentage inhibitory effect studies by Gomare et al on the activity of lipase using extracts of nine mentioned plants individually was found maximum by the extract of Piper longum (Linn.) as $35.32 \%$ compared to the rest of the plant extracts. ${ }^{35}$ Gabriella (2011) stated that the phospholipase activity of Malassezia spp. take part in the initiation of skin lesions, particularly in case of pityriasis versicolor (PV), although phospholipases should be measured as only one of the many factors involved in the complex interaction between the yeast and its host leading to the expansion of skin lesions. According to Sparber (2017), Malassezia species show lipid-dependency and lipolytic enzymes, such as lipases are required for the organism to obtain fatty acids from the surroundings.

\section{Gandhak}

In addition to keratolytic activity, sulfur has mild antifungal and antibacterial activity. However, its precise mechanism of action is unknown. When applied to skin, sulfur is thought to interact with cysteine, present in the stratum corneum, to form hydrogen sulfide 36 . Hydrogen sulfide can break down keratin, thus demonstrating sulfur's keratolytic activity. Pentathionic acid, which is toxic to fungi, is also formed by cutaneous bacteria as well as keratinocytes from topically applied sulfur ${ }^{37}$. In addition, the keratolytic effects may promote fungal shedding from the stratum corneum ${ }^{38}$.

Yavkshar Yavkshar a Carbonate of Potash is alkaline herbal formulation maintains buffer balance of skin $\mathrm{pH}^{39}$

Sarshap taila ${ }^{40}$ It has Lekhana, Kusthghna, Jantughna, Vednasthapana and Snehana properties. Oil is a skin and mucous membrane irritant, Emetic stimulant, digestive stimulant, antipruritic, sporostatic, antifungal41.Glucinolate, the pungent principle in mustard oil, has antibacterial, antifungal and anticarcinogenic properties ${ }^{42}$.

\section{DISCUSSION}

Edagajadi yoga (kwatha) is a polyherbal formulation consisting of Edagaja, Vidanga, Haridra, Daruharidra, Amlatasa, Kushta, Pippali. Amongst all the ingredients it can be observed that, the overall formulation is predominantly having katu (pungent), tikta(bitter), kashaya(astringent) rasa and ushna veerya with katu vipaka. These properties act on agni and helps in amapachana, forming proper ahara 
rasa which is kleda rahita (properly metabolized food). Tikta rasa is Deepana, Pachana lekhana, kledameda upashoshana, thus it helps in Ama pachana formed due to Nidanasevana. Tikta rasa is Raktaprasadana, Vishaghna, Kushthaghna, Kandughna and krimighna \& sweda upashoshana

Katu rasa is Vishaghna, Kandughna, Krimighna, Varnaprasadana. Acharyas in Ayurveda classics have mentioned katu rasa as "sneha-kleda mala anupahanti" which helps in normalizing the karma of mala i.e sweda (kleda vidrati), "Marganvivrunoti" which means it clears the Srotas and arrest pathogenesis by preventing Doshadushya samurcchana,

The tikshna guna present in all drugs corrects the dhatvagni (metabolism at the level of tissues) and almost all the ingredient have actions targeted on rasa, rakta, mamsa \& lasika, which are primarily responsible for kushtha samprapti. Laghu guna being akasha mahabhuta pradhana is urdhvagati sheela hence very easily removes dosha from urdhwabhaga i.e from chest neck face, back, upper extremities hence could help with healing main site of lesions in manifestation of sidhma kushtha

All the drugs have laghu, ruksha properties which checks the kandu caused by kapha dosha and balances the vikrit pitta with sheeta-pachaka property.

Amongst all the ingredients Aragwadha specifically has madhura rasa, sheeta veerya madhura vipaka \& guru, snigdha properties which is useful to pacify the pitta dosha in rakta. It also helps in sarvadhatu vardhan and act as rasayana. Kleda shoshana is done effectively by the kwatha form of drugs along with effective, safe and early metabolism of all pharmacologically potent active principles of formulation.

In the overall formulation some drugs like Aragwadha were found to have mridu virechaka properties and the rest has srotoshodhana \& vata anulomana as their major function. These properties are very critical in destroying doshasanghata which is very critical in kushta, as Acharyas have laid specific importance towards frequent shodhana in kushtha.

Gandhapashanadi lepa is combination of drug Shuddha Gandhak, Yavakshar, Sarshapa tail. Sidhma kushtha is Twakgata, that means, extremely superficial. Hence, here, in this study, Lepan Karma is selected for the treatment as per the indication by Acharya Sushruta. Acharya Charaka has described Lepana as "Sadya Siddhi Karaka" because external applications play a key role in the treatment of Kushtha.

Yavkshar \& sarshapa taila is found to pacify kapha-vata dosha due to katu. tikta rasa, ushna veerya, katu vipaka while gandhak has madhura rasa which helps in pacification of pitta dosha. Yavakshar with its Lekhana property is found to have deeper cleansing action on local site of lesion. The active principles of the Lepa reach to the deeper tissues through siramukha in swedavahi srotas \& stains it with its Sukshma \& Tikshna property. Due to its Ushna, Tikshna, Vishad \& Sukshma properties it deblocks the obstruction in swedavahi srotas \& allows the local toxins to flow out through the Sweda, thus clearing out the micro channels. The Ushna Virya of Gandhapashanadi lepa \& Snigdha Guna of its vehicle i.e. sarshapa taila causes pacification of Vata \& Kapha which forms the samprapti thus alleviating the symptoms.

\section{CONCLUSION}

Edagagajadi yoga is a herbal preparation mentioned under context of vatakaphaja kushtha by Acharya Charaka for the purpose of snana, pana, lepa. On reviewing various other texts Gandhak, yavkshar in base of sarshapa taila was found most effective with its targeted action on sidhma. These formulations are indicated in all types of kushtha and were found to be more effective in sidhma on critical analysis of its properties, active principles and pharmacological actions

While expounding over the line of treatment of Kushtha, Acharya Charaka has made it very clear that, let all the Kusthas be Tridoshaja, their treatment should be initiated only after considering the dominance of Dosha in them. The predominantly vitiated Dosha should be treated first \& the treatment of the other subordinate Dosha should be undertaken afterwards. The treatment plan of Krimi comprises three principles as i) Apakarshana ii) Prakritivighata iii) Nidana Parivarjana. In the case of Kushtha, Apakarshana means Samshodhana, Prakritivighata means Samshamana. Hence, the drugs selected here for kwatha yoga \& lepana karma acts as Prakritivighata chikitsa. Not much work is been done in this field, so clinical studies could be carried out with estimation of detailed Dermoscopic pattern of lesions in pityriasis versicolor with standard assessment criteria before and after treatment to prove its efficacy particularly against Malassezia spp.

\section{CONFLICT OF INTERESTS: none}

\section{REFERENCES}

\footnotetext{
${ }^{1}$ Hay RJ, Moore MK. Mycology. In: Burns T, Breathnach S, Cox N, Griffiths C, editors. Rook's Textbook of Dermatology. 6th ed. Oxford: Blackwell Science; 2004; p. 31.1-101.

${ }^{2}$ SILVA-LIZAMA ED. Tinea versicolor. International journal of dermatology. 1995 Sep; 34(9):611-7.

${ }^{3}$ Gupta AK, Bluhm R, Summerbell R. Pityriasis versicolor. Journal of the European Academy of Dermatology and Venereology. 2002 Jan; $16(1)$ :19-33.

${ }^{4}$ Borelli D, Jacobs PH, Nall L. Tinea versicolor: epidemiologic, clinical, and therapeutic aspects. Journal of the American Academy of Dermatology. 1991 Aug 1; 25(2):300-5.

${ }^{5}$ Roberts SOB. Pityriasis versicolor. In: Verbov JL, ed. Superficial fungal infections: new clinical applications in dermatology. Lancaster: MTP Press, 1986; 47-72.

${ }^{6}$ Agnivesha, Charaka, Charaka Samhita, Chikitsa Sthana 7/19, edited by Vaidya Yadavaji Trikamji Acharya Chaukhamba Surbharati Prakashana, Varanasi 2014; pg.no.252

${ }^{7}$ Midgley G, Gueho E, Guillot J. Disease caused by Malassezia species. Topley and Wilson's Microbiology and microbial infections. $1998 ; 4: 201-11$.

${ }^{8}$ Klenk AS, Martin AG, HEFFERNAN M. Yeast infections: candidiasis, pityriasis versicolor. FREEDBERG, IM; EISEN, AZ; WOLFF, K.; AUSTEN, KF. 2003; p. 32-34

${ }^{9}$ Dj K. Pityriasis versicolor--modern views on etiology, pathogenesis and therapy. Srpski Arhiv za Celokupno Lekarstvo. 1992 May 1;120(5-6):184-7.

${ }^{10}$ Khare C.P. (Ed.) Indian Medicinal Plants An Illustrated Dictionary Springer Science Business Media, LLC.2007; pp. 130.

${ }^{11}$ Patil UK, Saraf S, Dixit VK, Hypolipidemic activity of seeds of Cassia tora Linn, J. Ethnopharmacol, 2004; 90(2-3): 249-252

${ }^{12}$ Lemli J, Cuveela, J. Chromatography of anthrone glycosides of purgative drug, Planta Med., 1974; $26:$ p. 193 (Chemical Abstract, 1975, 82,35074X)

${ }^{13}$ Maitya T.K., Mandal S.C., Saha B.P. and Pal M., Evaluation of hepatoprotective potential of Cassia tora leaf extract, Nat. Prod. Sci, 1998; 4(4): 226.
} 
${ }^{14}$ Sivasankar C, Gayathri S, Bhaskar JP, Krishnan V, Pandian SK. Evaluation of selected Indian medicinal plants for antagonistic potential against Malassezia spp. and the synergistic effect of embelin in combination with ketoconazole. Microbial pathogenesis. 2017 Sep 1; 110:66-72.

${ }^{15}$ S.N. Madhavan, R. Arimboor, C. Arumughan, RP-HPLC-DAD method for the estimation of embelin as marker in Embelia ribes and its polyherbal formulations, Biomed. Chromatogr. 2011; 25 (5): p. 600-605.

${ }^{16}$ S.N. Madhavan, R. Arimboor, C. Arumughan, RP-HPLC-DAD method for the estimation of embelin as marker in Embelia ribes and its polyherbal formulations, Biomed. Chromatogr. 2011; 25 (5) p. 600-605.

${ }^{17}$ Toda S, Miyase T, Arich H, et al. Natural antioxidants. Antioxidative compounds isolated from rhizome of Curcuma longa L. Chem Pharmacol Bull, 1985; 33: p.1725-1728

${ }^{18}$ Arora R, Basu N, Kapoor V, et al. Antiinflammatory studies on Curcuma longa (turmeric). Indian J Med Res, 1971; 59: p. 1289-1295.

${ }^{19}$ Wuthi-udomlert M, Grisanapan W, Luanratana O, Caichompoo W: Antifungal activity of Curcuma longa grown in Thailand. Southeast Asian J. Trop. Med. Public Health, (2000);31: 178.

${ }^{20}$ Sharma R, Sharma M. Additive and inhibitory effect of antifungal activity of Curcuma longa (Turmeric) and Zingiber officinale (Ginger) essential oils against Pityriasis versicolor infections. Journal of Medicinal Plants Research. 2011 Dec 30;5(32): p. 6987-90.

${ }^{21}$ Singh I, Singh VP, Antifungal properties of aqueous and organic extracts of seed plants

against Aspergillus flavus and A. niger, Phytomorphology 2000;50: p. 151-157.

${ }_{22}^{22}$ Potdar D, Hirwani RR, Dhulap S, Phyto-chemical and pharmacological applications of Berberis aristata, Fitoterapia 2012; 83: p. 817-830.

${ }^{23}$ Prasad, Dr. Shyam \& Kaur, Darshpreet. In Vitro Anti Acne Activity of Ethanolic Extract of Stem of Berberis aristata. International Journal of Pharmacognosy and Phytochemical Research. (2017);9:10.25258/phyto v9i2.8061

${ }^{24}$ Verma H, Prasad SB, Yashwant. Herbal drug delivery system: A modern era prospective. Int J Curr Pharm Rev Res 2013;4(3):88-101.

${ }^{25}$ Pandey M, Debnath M, Gupta S, Chikara SK. Phytomedicine: An ancient approach turning into future potential source of therapeutics. J Pharmacogn Phytother 2011;3(1):113-7. 8.

${ }^{26}$ Yarnell E, Abascal K. Herbal medicine for acne vulgaris. Altern Complement Ther 2006;12(6):303-9. 6.

${ }^{27}$ Navodi WL, Ediriweera E.R.H.S.S., Ajith Kumara H.B.K. Sri Lankan traditional Virechana Karma with Ehela Peni (Cassia fistula) and application of Kaluwala Alepa (Alpinia malaccensis) in treatment of Sidhma Kushta (Pityriasis versicolor) -A case study. Int. J AYUSH CaRe. 2017;1(2): 1-6

${ }^{28}$ Dahanukar SA, Kulkarni RA, Rege NN. Pharmacology of medicinal plants and natural products. Indian J Pharmacol. 2000;32: S81-118

${ }^{29}$ Prashanth KV, Chauhan NS, Padh H, Rajani M. Search for antibacterial antifungal agents from selected Indian medicinal plants. J Ethnopharmacol. 2006; 107:182-8

${ }^{30}$ Lorenzini R, Mercantini R, and De Bernardis F. In vitro sensitivity of Malassezia spp. to various antimycotics. Drugs Exp Clin Res, 1985; 11(6):3935.

${ }^{31}$ Bhalodia NR, Nariya PB, Acharya RN, Shukla VJ. In vitro antibacterial and antifungal activities of Cassia fistula Linn. fruit pulp extracts, AYU 2012;33(1): 123-129.

${ }^{32}$ Bhalodia NR, Shukla VJ. Antibacterial and antifungal activities from root extracts of Cassia fistula 1.: An ethnomedicinal plant. Journal of Advanced Pharmaceutical Technology \& Research. 2011; Apr;2(2):104-109. DOI: 10.4103/2231-4040.82956.

${ }^{33}$ Madhavi, M. \& Mallika, G. \& Lokanath, N. \& Vishnu, M.N. \& Chetty, C. \& Sheikuduman, Mohamed Saleem. A review on phytochemical and pharmacological aspects of Saussurea lappa. Int. J. Life Sci. Med. Res (2012); 2. 24-31.

${ }^{34}$ Pandey, M.M., Singh, M., Rastogi, S. and Rawat, A.K.S.: Antimicrobial activity of methanolic extract and oil of Saus-surea costus roots. Nigerian J. Nat. Prod. Med. (2008); 12:95-98.

${ }^{35}$ Gomare, Komal \& Nagime, Pooja \& Mishra, Debendranath. Study of Inhibitory Effect of Plant Extracts on Lipolytic Enzymes Secreted By Malassezia furfur. IOSR Journal of Pharmacy and Biological Sciences. (2018); 13. 17-24.

${ }^{36}$ Gupta, Aditya K., and Karyn Nicol. "The Use of Sulfur in Dermatology." Journal of Drugs in Dermatology : JDD, vol. 3, no. 4, 2004 , pp. $427-31$.

${ }^{37}$ Sulfur and sulfur nanoparticles as potential antimicrobials: from traditional medicine to nanomedicine.

Rai M, Ingle AP, Paralikar P Expert Rev Anti Infect Ther, 2014 ;(10):969-978,

${ }^{38}$ M. N. Chatterji and R. Shinde Sulphur, Text book of Biochemistry. Jaypee Brothers Pubn, Delhi. 2nd Edn : 1995 : pg 811.

${ }^{39}$ National Toxicology Program (NTP). Corrositex: An in vitro test method for assessing dermal corrosivity potential of chemicals. The results of an independent peer review evaluation. 1999;p. 127

${ }^{40}$ Database on Medicinal Plants Used in Ayurveda, Published by The central council of Research in Ayurveda \& Siddha, New Delhi, Year of publication, 2001,1: 8

${ }^{41}$ Mejia, Beatriz \& Palou, Enrique \& López-Malo, Aurelio. Composition, Diffusion, and Antifungal Activity of Black Mustard (Brassica nigra) Essential Oil When Applied by Direct Addition or Vapor Phase Contact. Journal of food protection. (2015);78:p. 843-8. 10.4315/0362-028X.JFP$14-485$

${ }^{42}$ http://www.essential oils.co.za/essential_oils/mustard.htm\#oil properties 